\title{
Linkage between Tourism and Climate Change: A Study of the Perceptions of Stakeholders along the Annapurna Trekking Trail
}

\author{
- Shraddha Rayamajhi \\ shradha.rayamajhi@gmail.com
}

\section{Introduction}

This paper explores the relationship between tourism and climate change. It takes the perceptions of the stakeholders in the tourism sector, mainly the lodge-owners, guides and tourists in the Annapurna Trekking Trail.

Globally, the issue of climate change and tourism has been gaining significant ground. In this context similar kind of research is a requisite in our country, particularly when the fourth assessment report of the IPCC depicts HindukushHimalaya including Nepal as a "white spot", a region about which scientific information on climate change is limited or lacking altogether (NCVST, 2009).

Climate and Tourism have a very close relationship, and this relationship is even more pronounced for coastal tourism, mountain tourism and nature-based tourism (Moreno, 2010). "Tourism is considered to be a highly climate-sensitive economic sector similar to agriculture, insurance, energy, and transportation. Indeed, climate change is not a remote future event for tourism, as the varied impacts of a changing climate are even now becoming evident at destinations around the world" (Simpson et al., 2008, p. 12). Because of the importance of weather and environment to leisure demand, tourism is one of the sectors most likely to be affected by climate change. According to Simpson et al. (2008), emissions from tourism, including transports, accommodation and activities (excluding the energy used for constructions and facilities, for example) account for about 5 percent of global CO2 emissions. In 2005, tourism's contribution to global warming was estimated 
between 5 percent and 14 percent to the overall warming caused by human emissions of greenhouse gases (ibid).

Like all sectors tourism contributes to greenhouse gas emissions. However, it is also particularly susceptible to climate change impacts. With its close connections to the environment, tourism is considered to be a highly climate-sensitive economic sector. Because environmental conditions are such a critical resource for tourism, a wide-range of climate-induced environmental changes will have profound effects on tourism at the local and regional destination level. Changes in water availability, biodiversity loss, reduced landscape aesthetics, altered agricultural production (e.g., food and wine tourism), increased natural hazards, coastal erosion and inundation, damage to infrastructure and the increasing incidence of vectorborne diseases will all impact tourism to varying degrees (Simpson et al., 2008).

Despite significant growth in research on tourism and climate change, there are considerable gaps in research regarding tourism and climate change in specific regions like Nepal. Most of the published researches are based on coastal tourism and the remaining studies which are based on mountain tourism focus explicitly on skiing tourism. Thus, the impacts of climate change on tourism in the Himalayas-Hindu Kush are conspicuously absent from the literature. Though studies on impact of climate change on Himalayan glaciers and mountain areas in general are found (Bajracharya et al., 2007), impact of climate change on tourism in these areas is absent. In Nepal, very little study has been done about relationship between tourism and climate change. Only few existing studies include stakeholders as the basis of study.

In this context the key objective of this study is to explore the stakeholders' perception regarding climate change in the tourism industry in Annapurna Trekking area. Besides this, the study also tries to: find out the climate change related impacts perceived by tourism stakeholders; examine their level of awareness as well as their participation in climate change 
adaptation and mitigation; to find out the implications of climate change to tourists.

This study will be an added value in the field of tourism and climate change in Nepal with the perspective of stakeholders who are most affected by changes if there are any. The perception and knowledge of stakeholders if integrated into the existing climate change understanding will eventually enable an informed evaluation of changes, impacts and adaptation to climate change.

\section{Climate Change and Tourism}

Climate has a strong influence on the tourism and recreation sector. For example, climate influences the environmental resources that are the foundation for tourism/recreation, the length and quality of tourism and recreation seasons, the health of tourists, and even the quality of tourism experiences. Even though most tourism demand studies focus on economic variables (Crouch, 1994; Lim et al., 2008 as cited in Becken, 2010), climate has been identified as a key driver for tourism and an important destination attribute (Hu \& Ritchie, 1992 as cited in Becken). Climate is either the main tourism resource, for example, in the case of beach destinations (Kozak et al., 2008 as cited in ibid), or it acts as a facilitator that makes tourism activities possible and enjoyable (Martin, 2005).

Research on the inter-relationship between climate and tourism started around the 1950s (Scott et al., 2008). By the year 2007, climate change media coverage increased substantially and the tourism sector received increasing attention, in part due to the meeting organized by the UNWTO in Davos, Switzerland. This meeting highlighted the importance of climate as a tourism resource and the sensitivity of tourism activities to weather conditions and climate change sensitivity, which is manifesting itself already (Scott et al., 2008 as cited in Moreno \& Becken, 2009). Various reports have played important roles in fostering interest in climate change and tourism and more specifically on the negative impact on tourism, as they have given alarming 
projections of rising temperature, increasing sea-level, decreasing snow cover etc which has made ignoring the relationship impossible (IPCC, 2007; UNWTO, UNEP \& WMO; 2008, UNFCCC, 2011). A number of impact assessments have been produced some of which are global in nature (Ehmer and Heymann, 2008) and some of which focus on specific countries and destination types such as ski areas and coastal zones (Becken, 2004 \& 2007; Belle and Bramwell, 2005; Moreno, 2010; Sookram etc).

\section{Gap in Tourism and Climate Change Research}

Despite the significant growth in research on tourism and climate change there are considerable gaps in research in specific regions like Nepal. There is a research gap particularly in the context of developing countries and small island states. The widely cited 2006 review on the economic of climate change commissioned by the UK government by Sir Nicholas Stern (Stern, 2006) made brief references to tourism mostly of developed countries. Even in reports of IPCC, UNWTO, UNEP, and WTO, there are evidences of far greater knowledge of tourism and climate change with respect to adaptation and mitigation in the developed world than in the less developed countries and island states (UNEP et al, 2008). Large gaps appear to exist in research on the impacts of climate change on the Himalayas and how these impacts might affect tourism. Tourism is recognized by the IPCC as one of the most important industries in Asia, however, the lack of research is unfortunate. "Nature-based tourism is one of the booming industries in Asia, especially ski resorts, beach resorts and ecotourist destinations which are likely vulnerable to climate change; yet only a few assessment studies are on hand for this review" (Cruz et al., 2007).

\section{Study of Climate Change and Tourism}

Becken (2005) has done a study on climate change and tourism in Fiji. According to the study, tourism in island states is 
vulnerable to climate change because it may result in detrimental changes in relation to extreme events, sea level rise, and interruption in transport and communication. Her study analyses adaptation to climate change by tourist resorts in Fiji, as well as their potential to reduce climate change through reductions in carbon dioxide emissions.

Belle and Bramwell (2005) have also done a study on climate change and small island tourism. Backing up their study with the IPCC report, they say that small island states constitute a very high-risk group of countries as a consequence of their high vulnerability and low adaptive capacity and make a case for Small Island Developing States (SIDS). Moreno (2010) reviews climate change and coastal and marine tourism. Coastal areas have been identified as being highly vulnerable to climate change impacts. Moreno points out that a lot of tourism activities are shaped by weather conditions and climate change will affect these weather conditions as well as many of the other resources on which tourism activities are based. He confirms that the physical impacts of climate change include sea-level rise, beach erosion, increased frequency and intensity of extreme events, droughts, floods and changes in ecosystems' structures and biodiversity. Another study on coastal tourism (Moreno and Becken, 2009) presents a five-step vulnerability assessment methodology for tourism in coastal areas. Moreno believes that climate change is intimately related to human intervention, and that a major difference between current and historical changes in the climate system is that it is not occurring due to natural causes but is driven by human activities (p. 163).

\section{Stakeholder's Perception Analysis in Studying Relationship between Tourism and Climate Change}

Stakeholder analysis refers to a set of tools and processes used to identify and describe stakeholders on the basis of their attributes, interactions, and interests related to a given issue (Ramirez, 1999 as cited in Cerveny, 2005). For studying impact 
of climate change on coastal and island tourism many researchers have used stakeholders' assessment. (See Moreno and Becken 2009; Becken, 2005; Belle \& Bramwell, 2005).

Stakeholders in this study are people who are directly or indirectly related to tourism and who will be affected by any change in tourism patterns because of change in climate. The study therefore takes the lodge owners and guides along the trail of the study site as well as trekking tourists who visit this site who might be or are affected by changes in the climate. Though these people are not experts and do not back up their experience with scientific evidence, the kind of observation they make and experience by being in the situation are very useful in knowing the impact of climate change on tourism.

Belle \& Bramwell (2005) in their study of climate change and small island tourism suggest that understanding and responding to climate change covers issues of great complexity, involving many different organizations, spatial and time scales, and academic disciplines. It necessitates the integration of knowledge from a very wide range of sources, both academic and lay people. It also requires an understanding and involvement of the many actors who are affected, including citizens in general. There is a need to build from traditional natural science and climate modelling, but equally necessary is understanding the kind of experience and challenges (if there are any) tourism service providers and tourists are facing on day to day basis. A full appreciation of the issues of tourism and climate change requires that scientific research is combined with research on perception, knowledge and expertise of local stakeholders to enable an informed evaluation of impacts, vulnerability and adaptation to climate change.

In Nepal some studies have been conducted using stakeholders' assessment method to understand the impacts of climate change on various sectors (Practical Action, 2010; Oxfam International, 2009; NCVST, 2009). Practical Action used the stakeholders' analysis to know community perception on warming and 
precipitation and to know the impact of climate change on various sectors like water resources, agriculture, infrastructure, forest and biodiversity and human health. Similarly, Oxfam International (2009) used local people in 14 communities in seven districts in the three major ecological zones to know their experiences and perceptions of climate change.

NCVST report (2009) has also used stakeholders' assessment. The report argues that though there is a lack of extensive scientific research and data about Nepal which has limited the ability of the global scientific community to evaluate the implications of climate change for the region, there is another source of information - the local people. The report says that in contrast to the "eagle's eye view", the local people provide a "toad's eye view" rooted in the civic science of traditional knowledge and on-the-ground observation regarding the impacts of climate change (NCVST, 2009).

Even when it comes to adaptation, local observations and perceptions are crucial as they motivate behavior. This behavior, in turn, shapes livelihood systems, infrastructure decisions and economic activity in ways that centralized, topdown strategies cannot. As a result, understanding the observations and perceptions emerging at the grassroots level has fundamental importance for developing systems that are adaptive and resilient to climate change.

Stakeholders' perception assessment thus is a very useful and effective way of knowing the ground reality of the effects of climate change. Stakeholders like lodge owners in trekking trails and tourists will be important in knowing the kind of changes the lodge owners are witnessing in their everyday business due to what could be the effects of climate change. Also knowing the perceptions of tourists about climate change could be useful in knowing and predicting the future of tourism in our country if the present trend of climatic changes keeps continuing. 


\section{Climate Change and Tourism in Nepal}

Neupane and Chettri (2009) acknowledge that the literature on impacts of climate change in mountain tourism focuses on reduced snow cover and its impact on the ski industry, which is not pertinent in the Himalayas. Through the only literature on tourism and climate change in Nepal (while this study was conducted), Neupane and Chettri argue that seasonality can affect tourism in several ways. First, it creates physical conditions (e.g. the absence or presence of snow, rain and wind during travel) that make tourists prefer to travel to destinations where there is enough snow, rain and wind to support the activities, or have minimum disturbances. Secondly, changes in temperature and humidity cause discomfort to individual tourists and affect their vacation plans (de Freitas, 2003; Martin, 2005 as cited in Neupane \& Chettri, 2009). Thirdly, clouds can block the views of mountains and reduce the aesthetics of various destinations and attractions (Neupane \& Chettri, 2009).

Neupane and Chettri conclude that under changing climatic conditions, parks in the three physiographic regions - Mt. Everest National Park, Annapurna Conservation Area and Chitwan National Park - face different consequences that can have deleterious effects on nature-based tourism. Parks in the mountains, particularly north-eastern Nepal, will experience more avalanches and glacial lake outburst floods, while the hills will face more landslides, debris flows and flash floods, and the lowland Terai will see more flood-related hazards (p. 115). This being one of the first papers examining the impact of climate change on nature-based tourism in Nepal suggests that there is a need for local data to assess the potential consequences at each nature-based tourism destination. Indeed, there is a dearth of studies on linkages between tourism and climate change in Nepal.

Most of the national reports (MoEST, 2008; NCVST, 2009; Oxfam, 2009; Practical Action, 2010) which study climate change and its impacts in various sectors fail to mention 
tourism as an area which will be affected by climate change. Tourism has been given no space in these reports, which makes it even more important to highlight the issue of climate change and tourism.

\section{Climate Change Scenario in Nepal}

Though its emission level is lowest in the world measuring only $0.025 \%$ of global greenhouse gas (GHG) emissions, like other GHG gas non-emitting countries, Nepal is extremely vulnerable to climate change (Dhungel, 2009). Nepal is one of the ten most vulnerable developing countries because of its geography, poor physical infrastructure and the low level of development of its social sector (Agrawala et al., 2003). The IPCC's 2007 Fourth Assessment Report is characterized by a "Himalayan gap"; it includes very few references to scientific studies conducted in this region. Its complicated geography makes Nepal come under the special category as specified in UNFCCC Principle 4.8 , which recognizes the special position of mountainous and landlocked countries.

Temperature observations in Nepal over the last twenty-five years show an increasing trend at the rate of $0.06{ }^{\circ} \mathrm{C}$ per year (MoEST, 2008). The warming is found to be more pronounced in the higher altitude regions of Nepal such as middle mountain and Himalaya, while it is significantly lower or even lacking in Terai and Siwalik regions. There is no substantive change in annual and monsoon precipitation in Nepal (APN, 2007 as cited in Practical Action, 2010; Shrestha et al. 2000 in Practical Action, 2010). However, a clear decreasing trend has been seen in the number of annual rainy days during the last four decades (APN, 2007 as cited in Practical Action, 2010).

\section{Climate Projections}

The following climate projections have been made for Nepal by Agrawala et. al (2003); MoEST, (2008) and NCVST (2009):

- Significant and consistent increase in temperatures 
projected for Nepal for the years 2030, 2050 and 2100 across the various climate models: that it could be warmer in Nepal by $4^{\circ} \mathrm{C}$ in winter and 2.5 to $3^{\circ} \mathrm{C}$ in summer. Mean annual temperature increasing by $1.4^{\circ} \mathrm{C}$ to 2030 , by $2.8^{\circ} \mathrm{C}$ to 2060 and by $4.7^{\circ} \mathrm{C}$ to 2090 .

- Temperature increases greater in higher elevations than in lower ones.

- Projected temperature increases are lower in Eastern Nepal than in Western and Central parts.

- Increases in temperatures are somewhat larger for the winter months than the summer months.

- There will be increasing frequency of hot days and hot nights.

- Rainfall is expected to increase in Eastern and Central Nepal but decrease in Western Nepal.

- Overall winter rains are expected to decrease.

\section{Tourism in Nepal}

Trekking is the most popular tourism activity in Nepal. About 43 percent of all international visitors participate in trekking through the natural and cultural landscapes of the Nepalese Himalayas (MCTCA, 2004). Nepal's tourism is primarily nature-based. Mountaineering, trekking, white water rafting and safari tours into the jungles are the main forms of nature-based tourism activities in Nepal. The prospect of climate change as a result of global warming, however, has heightened concern over the ability of this region to maintain its natural beauty and, consequently, its tourism base (Alam \& Regmi, 2004).

The natural protected areas encompass more than $18 \%$ of the total area of the country (NTB, 2001). However, among the 16 protected areas, $98 \%$ of all trekkers visit four protected areas. Popularity-wise, NTB (2010) shows that a majority of tourists went to Chitwan National Park (84,322), Annapurna Conservation Area $(74,161)$ and Sagarmatha National Park $(31,189)$. Other popular destinations are Shivapuri Nagarjun National Park $(11,957)$ and Langtang National Park $(10,603)$. There has been a steady increase in visits to natural and 
protected areas in Nepal, with an annual growth rate of 10 to 30\% during the last decade (Travel Industry Association, 2003; Nyaupane and Thapa, 2006).

Looking at the most popular tourist activities in the country (mountaineering, trekking) it can be said that weather and climate are important parameters for these activities. The kind of climatic impacts a destination is experiencing will have an effect on the timing of certain activities and it influences participation rates (Moreno, 2010). For example, the best time for trekking in Nepal is September to November and March to May. However, trekkers might change their plans if there is extended monsoon.

\section{Methodology}

Respondents: For the purpose of this research, 70 respondents were selected through snow-ball sampling method. Snow-ball sampling method was used as a fixed number of lodge owners. Guides and trekkers could not be chosen from a sample group. There were no lists or other obvious sources to locate the stakeholders and hence snow-ball sampling method would be a very effective method to identify the respondents. The respondents for this study were 35 lodge owners and guides in the Annapurna Sanctuary trekking trail and 35 trekking tourists who visited this area in September 2010.

Data Collection: Structured interview schedule with mostly close-ended questions were used. Besides this, quotes from the respondents were collected.

Study Site: The study site for this research was Annapurna Sanctuary Trek, a part of Annapurna Conservation Area (ACA) and the country's largest protected area $\left(7,629 \mathrm{~km}^{2}\right)$. The research started from Dhampus and ended at Ghandruk (See Map: Figure 1). The fieldwork for this study took place in the month of September in 2010. The researcher spent 12 days in the trekking trail, interviewing lodge-owners, guides and trekking tourists who visited this area. 
Figure 1: Map of Annapurna Sanctuary Trekking Trail

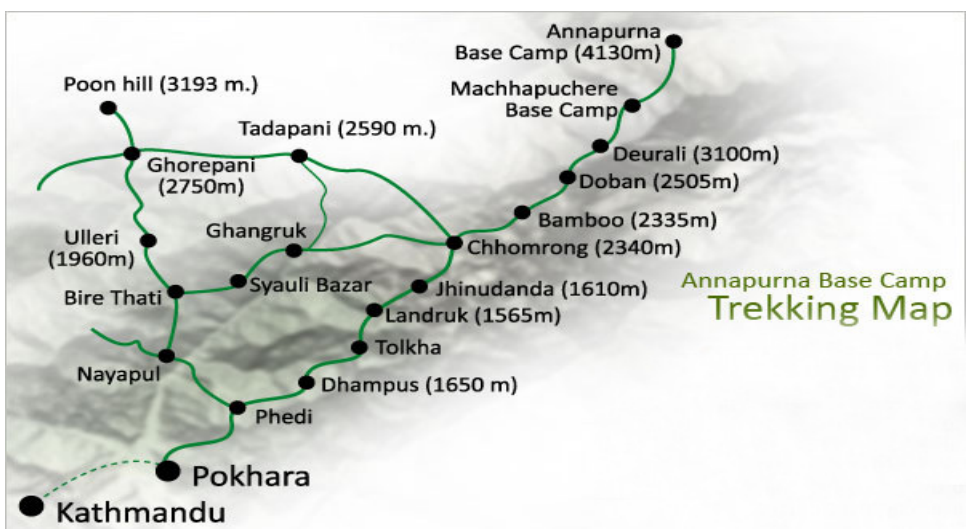

Source: www.allnepal.com

\section{Findings}

Tourists' Priority for holiday in Annapurna Trekking trail and their experience

Around 73.6 percent of the respondents said that mountain and glaciers were the most important aspects of their holiday in Annapurna area. While 44.25 percent attributed to nice weather, 34.95 percent of them respondents said that "a clean environment" was the most important aspect of their holiday. Only 7.1 percent said that weather was not important for them.

It can be noted that the tourists placed a very high importance on 'mountain and glaciers' and 'nice weather' to be an important aspect of their holiday in Annapurna area besides other aspects like the people who reside in the area, good food and culture. This could mean that decision regarding the visit to this area might change if any change occurred in these two aspects.

Figure 2 shows that for 84 percent of the tourists, mountain destination was a very important factor when they decided to visit Annapurna area. For 48 percent of the respondents climate 
Figure 2: Importance of the following factors when tourists decided to visit Nepal/Annapurna

\begin{tabular}{|c|c|c|c|c|}
\hline \\
\hline \\
\hline \multirow{2}{*}{\multicolumn{5}{|c|}{$60 \%$}} \\
\hline & & & & \\
\hline \multicolumn{5}{|l|}{$40 \%$} \\
\hline \multicolumn{5}{|l|}{$30 \%$} \\
\hline \multirow{2}{*}{\multicolumn{5}{|c|}{$\begin{array}{l}20 \% \\
10 \%\end{array}$}} \\
\hline & & & & \\
\hline & $\begin{array}{c}\text { Not } \\
\text { important at } \\
\text { all }\end{array}$ & $\begin{array}{l}\text { Not that } \\
\text { important }\end{array}$ & Important & $\begin{array}{l}\text { Extremely } \\
\text { important }\end{array}$ \\
\hline Mountain destination & $0 \%$ & $5 \%$ & $11 \%$ & $84 \%$ \\
\hline Climate & $15 \%$ & $20 \%$ & $48 \%$ & $17 \%$ \\
\hline General image & $25 \%$ & $24 \%$ & $41 \%$ & $10 \%$ \\
\hline Cheap destination & $25 \%$ & $32 \%$ & $39 \%$ & $4 \%$ \\
\hline
\end{tabular}

Source: Field Survey, 2010

was an important factor, and for 41 percent of the tourists general image of the destination was important when they decided to visit the area. Nepal being a cheap destination for tourists was also an important factor for 39 percent of the respondents. Tourists gave importance to mountain destination, climate, general image respectively for visiting Nepal and particularly the Annapurna area. This is telling of how the tourists give importance to mountain destination and climate and their priorities might change if any changes occurred in any of the factors.

In their actual experience, climate-related factor like the 'weather' was the most disappointing to the tourists (57\% very disappointing and $75 \%$ disappointing). Non-climatic factors like accommodation and people were not disappointing to them.

Tourists' Perception about Implications of Climate Change to Nepal's Tourism Industry

How tourists "perceive" the impact of climate change on a destination is an important cue for anticipating changes in 
tourist behaviour. It is not known how significant the discrepancies are between actual and perceived climate change. However, this is important for anticipating changes in tourist behaviour (Moreno, 2010).

Ninety four percent of the tourists said that there will be implications for Nepal as a tourist destination due to climate change.

Middle-aged (35-44) female from Scotland: "The late monsoon and flooding is stretching onto the usual tourist season in Nepal which will definitely impact tourism negatively."

Young male from Belgium: "The heavy rainfall in the first few days of the trek was really a nuisance, this greatly hampers the pleasant trekking experience for the tourists who might not come if the erratic rainfall continues."

Sixty eight percent of the respondents said that there will be implication for tourists like them due to climate change. The probability of tourists going to alternative destinations or changing their travel plans cannot be overruled if negative weather-related impacts continue in this region. In similar lines, 54.3 percent of the respondents felt that a changing climate caused by Green House effect is somewhat dangerous for Annapurna area. Forty percent felt that it is extremely dangerous for the area. A large percentage of the trekking tourists believe that changing climate is either dangerous or extremely dangerous for the Annapurna area.

Determining the Future of Nepal's Tourism Industry as a Result of Climate Change

Various factors play a role in determining the future of Nepal's tourism industry. This section will try to see what kind of factors would prevent tourists from visiting the country in the 
future. It will try to analyze whether these factors are climatic or non-climatic in nature.

Figure 3: Factors that could prevent tourists from visiting Nepal in the future

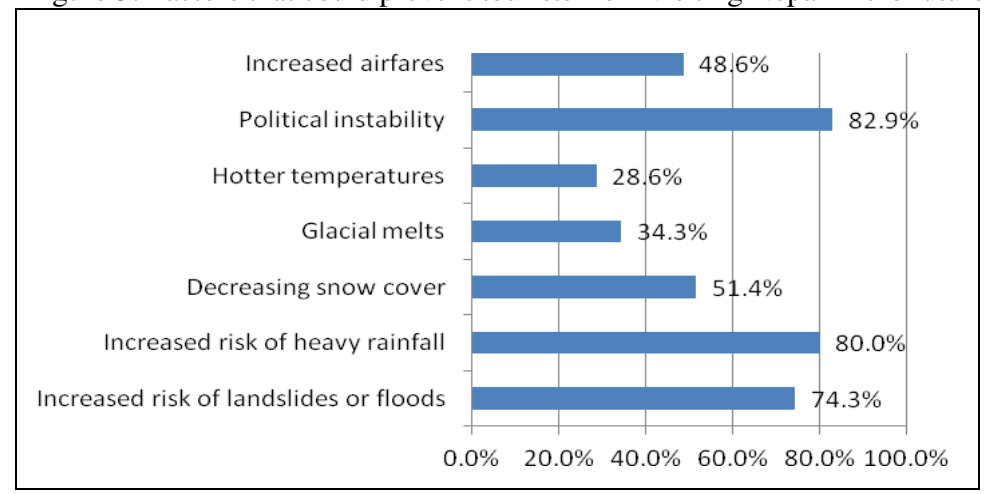

Source: Field Survey, 2010

According to the findings (Figure 3), 82.9 percent of the respondents said that political instability in the country could prevent them from visiting Nepal in the future. While 80 percent said increased risk of heavy or erratic rainfall could prevent them from visiting Nepal in future, 74.3 percent said increased risk of landslides or floods could prevent them from visiting Nepal in the future. In the same way, 51.4 percent of the respondents said decreasing snow cover would discourage them from visiting Nepal in the future whereas 48.6 percent said that increased airfares would be the main discouraging factor. Only 34.3 percent of the respondents said that glacial melts would deter their visit to Nepal, and 28.6 percent mentioned hotter temperature as causative to a deferred visit.

More than climate change, political instability in the country could prevent tourists from visiting Nepal in the future. But besides this non-climatic factor, 80 percent of the respondents said that increased risk of erratic rainfall would equally hinder their orientation to Nepal. Similarly, increased risk of landslides and floods could also deter their visit. While risk of rainfall, landslides and floods, and to some degree decreasing snow cover would disorient them in the future, climatic factors like 
glacial melts and hotter temperatures would not bother them as much.

There is a possibility that tourists will opt for alternative places if negative impacts of climate change are high in a destination. Some 60 percent of the tourists said that they would opt for alternative tourist destinations if the negative impacts continued.

\section{Tourists' Awareness Regarding Climate Change and Tourism}

The field survey found that the tourists are aware of the issue of climate change. For instance, when asked if there were any specific examples of climate change they know about, these were some responses:

Middle-aged female respondent from Scotland: "There has been more severe weather all around the globe."

Middle aged female from Germany: "We can see the later beginning of monsoon period."

Figure 4: Tourists' perception on contribution of tourism to climate change

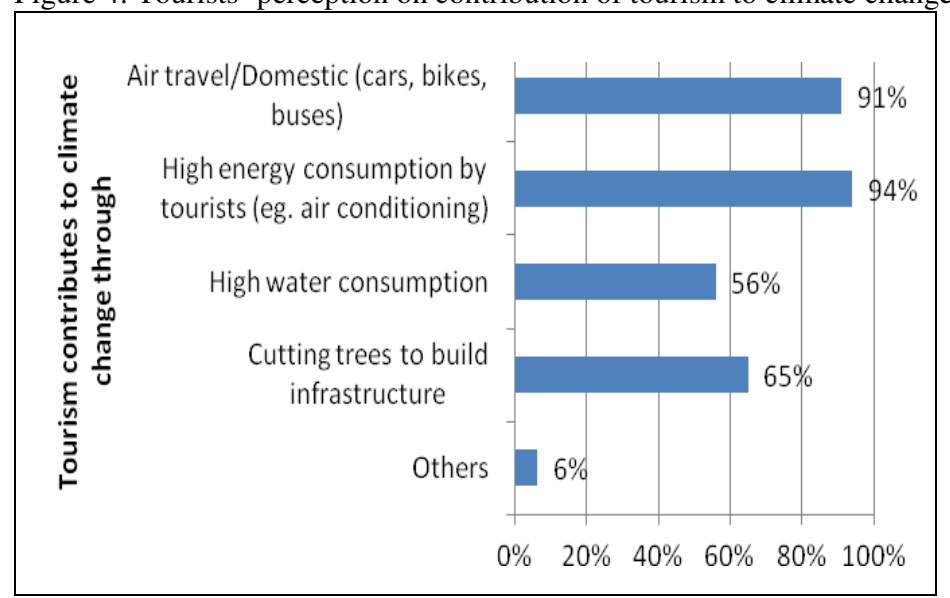

Source: Field Survey, 2010 
Tourists are more aware of climate change than lodge owners. Figure 4 shows 94 percent tourists who said that high energy consumption by tourists, e.g air conditioning, is the prime contributor to climate change through tourism. A high percent of 91 also said that air travel and domestic travel equally contribute to climate change.

\section{Perceptible Changes in Climate and Relation to Business}

The perceptible changes in local climate observed and experienced by the lodge-owners and guides who have been in the Annapurna area for so many years is a very important firsthand information regarding climate change and its possible effects in this region.

Figure 5: Perceptible changes in the local climate

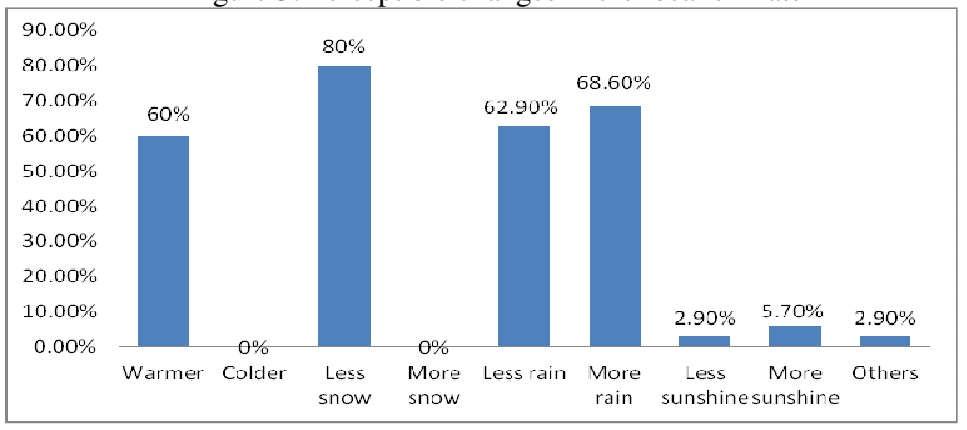

Source: Field Survey, 2010

Sixty percent of the respondents said that it was warmer than before. The finding is consistent with other findings by (Oxfam 2009, Practical Action 2010) in other regions of Nepal which shows a warming trend. While 80 percent mentioned about decreased snow, 62.9 percent considered lower rain, and 68.6 percent attributed more rain. These people actually said that rainfall pattern has been erratic in recent years.

It used to be cold only from November but this year it is cold from October itself, thus winter season has increased by one month this year."- Lodge owner 
Dhampus." (Lodge owner at Annapurna Base Camp said the same thing)

Winter season has lessened because snow has decreased. Earlier because of the snow the trails used to be blocked for days but now it is not the case." - Lodge-owner at Bamboo

Sixty nine percent of the lodge-owners and guides said that there have been changes in the tourism season. In some years the season started earlier and in some years later. Forty nine percent of the respondents said that the change in climate had relation with the work they did. Thirty four percent perceived no relation, while 17 percent of them were not sure if the changing climate had any relation with their work.

Some of the responses of the lodge owners and guides about the relationof the changing climate to their business are as follows:

"Even in the season the guests are very few because of
the heavy rainfall" - Lodge-owner in Landruk
"What I feel is that the trekkers who come to the area
come here because of the snow-capped mountains and if
the snow keeps on decreasing the tourists will eventually
stop coming to the area and our business will
automatically stop" - Guide in Dovan
"Due to bad weather and heavy rainfall my crops get
destroyed and I have to buy all my vegetables from the
nearby city which is very expensive" - Old female
lodge-owner in Ghandruk

Despite the change in climate, as perceived by the stakeholders, and the shift in tourism seasons that varies every year, 62.9 percent said that the number of tourists has been increasing. 
Kind of Energy Resources Used to Run Business

Tourist accommodations use a wide range of energy resources. According to the field survey, 96.3 percent of the lodge owners rely on LPG gas for cooking. Some 77.8 percent of the lodges have solar power which they mostly use for hot water for shower. Electricity is mostly generated from micro hydropower with 74.1 percent of the respondents relying on this source of energy.

For cooking purposes, 66.7 percent use kerosene and very few, 18.5 percent, use wood as the ACAP rule does not allow them to cut trees. Because of its terrain, the use of petrol and diesel is almost nil. Energy consumption and resulting greenhouse gas emissions seems minimal in this area as besides the use of LPG most of the business (77.8\%) use renewable source of energy (solar energy).

\section{Perception on the Impact on Tourism Industry}

Most of the nature-based tourism activities in the Himalayas are weather-sensitive. For example, rain and foggy conditions significantly decrease the quality of the trekking experience in the Himalaya (Nyaupane \& Chhetri, 2009). In similar lines, of the lodge owners and guides who said that climate change is imminent, 83 percent believed it would have an impact on Nepal's tourism industry. They said that impact would mostly be negative which might affect the number of tourist flow in the area.

Talking about the change in temperature, it has not been so significant to the extent of causing discomfort to the tourists. Forty six percent of the lodge-owners and guides in the Annapurna area said that increase in temperature would not produce significant changes on tourists' level of comfort as the temperature rise was not that significant. Because the rise in temperature has not been so significant as to make people feel uncomfortable, it does not seem to be a cause of alarm for tourists. 


\section{Positive Impacts of Climate Change}

While a larger percentage said that climate change has no positive impact on the trail, some 23 percent of the lodgeowners and guides believed that there were positive impacts of climate change. One is that people who come from sea-level can also trek as temperatures are rising; it won't be as cold as before, making trekking experience more pleasant. "Tourists are still increasing so there hasn't been any
change due to climate change so this is positive in a
way" - Guide in Sinuwa
"Since the weather is not as cold as it used to be before,
more tourists can come now. Also since people know
that snow is decreasing they will start coming more
before the snow cover decreases considerably as they
would want to see the mountains in their original form
before it gets degraded due to climate change"- Guide in
ABC

"Even in December it's not that cold so more tourists can come, though climate change is environmentally bad it is good for our tourism as the tourist number might increase." - Guide in Dovan

"I don't know why it is happening but I have started growing more vegetables. I think due to rise in temperature we are being able to grow cucumbers and chilies which was not possible before" - Old female lodge owner in Ghandruk ( $1^{\text {st }}$ lodge of Ghandruk)

Awareness on Relation between Tourism and Climate Change

The stakeholders were found to be aware of a number of natural calamities, but were unsure whether these were climate change impacts. Nor were they aware that the changes would have an effect on tourism. They were only aware about phenomena like landslides, decreasing snow cover, erratic rainfall, rise in 
temperature among others in isolation, and through personal experience, but not with relation to climate change and tourism.

Sixty six percent of the respondents were not sure about the greenhouse gas emission from tourism which contributes to climate change. Awareness among stakeholders was found to be low as a majority of them were not sure how tourism contributes to the change in climate. The number of such people who showed such ignorance was 77.1 percent. Only a small number opined that tourism contributes to climate change through air travel and domestic use of vehicles used for tourism or cutting trees for firewood and construction. Though a few of the respondents showed some awareness about tourism's contribution to climate change, this percentage was very low compared to those who practically had no idea about tourism's contribution to climate change.

\section{Adaptation and Mitigation}

While 84.6 percent lodge-owners used solar energy for electricity and hot water, 26.9 percent said they took up measures like "not using wood" or reducing unnecessary energy use. The overall picture is that the lodge owners are using renewable sources of energy and doing their best to reduce energy for their own business purposes which directly contributes to climate change mitigation. A huge majority of lodge-owners at Annapurna Sanctuary trekking area use solar energy thus knowingly or unknowingly contributing to mitigation of climate change. Besides, it can be noted that a number of other greenhouse gas mitigation measures are in place like using energy efficient light bulbs etc even though it is motivated by business purpose and not for climate change mitigation.

However, 65.7 percent of the respondents were not sure about how the future effects of climate change can be offset. This apparent ignorance of lodge-owners and guides about an important issue at hand maybe a lost opportunity for adaptation and mitigation to climate change impacts. There is a general 
lack of awareness of climate change and its probable impacts and the stakeholders do not necessarily relate the problems that they may be facing to climate change. Overall, the stakeholders feel that the major barrier to implementing climate change mitigation and adaptation measures are 'lack of knowledge' and lack of 'incentives by the government'.

\section{Conclusion}

From discussions above, we can infer that the tourists might change the travel pattern in the future or maybe even the destination if weather continues to disappoint them. There were perceptible changes in the climate, such as rising temperature (though not significant), less snow, erratic rainfall, changes in summer and winter months. However, regardless of the perceived change in climate and the shift in tourism seasons that varies every year, the number of tourists has been increasing in this area. It was found that though the erratic rainfall directly hampered the lodge-owners' business. Decrease in snow cover, glacial melts and the rise in temperature have not been too significant to have an impact on their business. While risk of increased intensity of rainfall, landslides, floods among others would prevent them from visiting in the future, other results of climatic changes like glacial melts and hotter temperatures would not bother tourists much. Though a little temperature rise may not affect the trekking tourist significantly, the perceived change in temperature and hence the attractiveness of the mountains could have some influence in tourists' decision in the future. However, immediate changes in their travel pattern solely due to increase in temperature doesn't look very likely.

Though climate change may have both negative and positive impact on a destination, the lodge owners and guides were largely of view that climate change's impact would be negative. There were definitely a handful of lodge-owners who felt that climate change could actually have some positive impacts. For now, the tourists are more worried about the political instability 
of the country than changes like decreasing snow-cover, which rather seems a distant reality.

The lodge-owners and guides were aware of a number of changes in the nature and environment and natural disasters. But though they were aware of these phenomena, they were not aware that these were potentially the impacts of climate change. They were largely unaware about how tourism contributes to climate change.

The energy consumption and resulting greenhouse gas emissions seems minimal in this area. Besides the use of LPG, most businesses rely on renewable sources of energy (solar), and are self-reliant for electricity mostly through hydropower. Knowingly, or unknowingly the lodge owners are contributing to climate change mitigation. However, with few exceptions of adaptation and mitigation efforts, initiatives are not systematically explored and implemented. Though the huge potential for solar energy has been used, such technology can be taken up more aggressively if adaptation and mitigation in this area is to be initiated seriously. People were already involved in activities which would contribute to the mitigation of climate change. But they had very low level of awareness about these mitigation strategies.

Using stakeholder's perception analysis incorporating the views of lay people has proved to be a good method of studying the linkages between tourism and climate change in Annapurna Sanctuary trekking area. Understanding the kind of experience and challenges tourism service providers and tourists are facing in day to day basis is as important as building theories in traditional natural science. If the information collected from the lodge-owners and guides who have lived and worked as tourism service providers for years, and from tourists who are aware about climate change and can change their travel behavior according to their experiences, are backed up by extensive scientific data, a true, complete knowledge on the linkages between tourism and climate change can be expected. 


\section{References}

Agrawala, S., Raksakulthai, V., Aalst, M. v., Larsen, P., Smith, J., and Reynolds, J. (2003). Development and climate change in Nepal: Focus on water resources and hydropower. Paris:Organisation for Economic Cooperation and Development (OECD).

Alam, M., and Regmi, B. R. (2004). Adverse impacts of climate change on development of Nepal: Integrating adaptation into policies and activities. Dhaka: Bangladesh Centre for Advanced Studies (BCAS).

Bajracharya, S. R., Mool, P. K., and Shrestha, B. R. (2007). Impact of climate change on himalayan glaciers and glacial lakes: Case studies on GLOF and associated hazards in Nepal and Bhutan. Kathmandu: ICIMOD/UNEP/ROAP.

Becken, S. (2010). The importance of climate and weather for tourism. Land environment and people. Retrieved January 6, 2011 from http://www.lincoln.ac.nz/PageFiles/6698/WeatherLitRe view.pdf .

Becken, S. (2007). Tourists' perception of international air travel's impact on the global climate and potential climate change policies. Journal of Sustainable Tourism, 15 (4), 351-368.

Becken, S. (2005). Harmonizing climate change adaptation and mitigation: The case of tourist resorts in Fiji. Global Environmental Change - Part A, 15 (4) 381-393.

Becken, S. (2004). How tourists and tourism experts perceive climate change and carbon-offsetting schemes. Journal of Sustainable Tourism, 12 (4), 332-345.

Behringer, J., Buerki, R., and Fuhrer, J. (2000). Participatory integrated assessment of adaptation to climate change in Alpine tourism and mountain agriculture. Netherlands: Kluwer Academic Publishers.

Belle, N., \& Bramwell, B. (2005). Climate change and small island tourism: Policy maker and industry perspectives in Barbados. Journal of Travel Research, 44, 32-41. 
Cerveny, L.K. (2005). Tourism and its effects on Southeast Alaska communities and resources: Case studies from Haines, Craig, and Hoonah, Alaska. United States Department of Agriculture. Retrieved December 12, 2011 from http://www.fs.fed.us/pnw/publications/ pnw_rp566/pnw_rp566a.pdf.

Chaulagain, N. P. (2006). Impacts of climate change on water resources of Nepal: The physical and socioeconomic dimensions. Universität Flensburg.

Cruz, R.V. et al. (2007). ... In M. L. Parry et al. (eds.), Climate change 2007: Impacts, adaptation and vulnerability (pp. 469-506). Cambridge: Cambridge University Press.

Dhungel, K. R. (2009). Nepal and climate change. Retrieved March 6, 2011 from http://www.nepalnews.com/home/index.php/guestcolumn/1354-nepal-and-climate-change.html.

Ehmer, P., and Heymann, E. (2008). Climate change and tourism: Where will the journey lead? Germany: Deutsche bank Research.

IPCC. (2007). Climate change 2007: Synthesis report. Geneva: Intergovernmental Panel on Climate Change.

Linden, P.J. and Hanson, C.E. (eds). Climate Change 2007:

Impacts, Adaptation and Vulnerability. Cambridge.

Cambridge University Press.

Martin, G. (2005). Weather, climate and tourism:

Ageographical perspective. Annals of Tourism Research, 32 (3), 571-591.

MCTCA. (2004). Annual statistical report 2004. Kathmandu: Ministry of Culture, Tourism and Civil Aviation.

MoEST. (2008). Nepal stock taking report on climate change: National capacity self-assessment for global environment management. Kathmandu: Government of Nepal, Ministry of Environment, Science \& Technology, MoEST/UNDP/GEF.

MoEST. (2009). Nepal stock taking report on climate change.

Kathmandu: Government of Nepal, Ministry of Environment, Science and Technology (MoEST)/UNDP/GEF. 
Moreno, A. (2010). Climate change and tourism: Impacts and vulnerability of coastal Europe. Netherlands:

Universitaire Pers Maastricht.

Moreno, A., \& Becken, S. (2009). A climate change vulnerability assessment methodology for coastal tourism. Journal of Sustainable Tourism, 17 (4), 473488.

NCVST. (2009). Vulnerability through the eyes of vulnerable: Climate change induced uncertainties and nepal's development predicaments. Institute for Social and Environmental Transition-Nepal (ISET-N, Kathmandu) and Institute for Social and Environmental Transition (ISET, Boulder, Colorado) for Nepal Climate Vulnerability Study Team (NCVST).

Nepal Tourism Board. (2001). National ecotourism strategy and marketing programme of Nepal. Kathmandu: Nepal Tourism Board.

Nepal Tourism Board. (2011/12). Annual Operational Plan. Retrieved May 8, 2011 from

http://www.welcomenepal.com/corporate/images/AOP2011-12.pdf.

Neupane, G., and Chhetri, N. (2009). Vulnerability to climate change of nature-based tourism in the Nepalese Himalayas. Tourism Geographies, 95-119.

Nyaupane G. P., and Thapa B. (2006). Perceptions of environmental impacts of tourism: A case study at ACAP, Nepal. International Journal of Sustainable Development and World Ecology,...

Oxfam International. (2009). Even the Himalayas have stopped laughing. Climate change, poverty and adaptation in Nepal.

Practical Action. (2010). Impacts of climate change: Voices of the people....

Scott, D. et al. (2008). Climate change and tourism:

Responding to global challenges. UNWTO-UNEP.

Simpson, M.C. et al. (2008). Climate change adaptation and mitigation in the tourism sector: Frameworks, tools and practices. Paris: UNEP, University of Oxford, UNWTO, WMO. 
Sookram, S. (n.d.). Climate change on the selected Caribbean countries. Caribbean Development Report, ECLAC.

Stern, N., (2006). The stern review: The economics of climate change. Retrieved from www.hmtreasury.gov.uk/independent_reviews/stern_re view_economics_climate_change/stern_review_report. cf.

UNFCCCC. (2011). Official website.

http://unfccc.int/essential_background/items/6031.php

UNWTO, UNEP \& WMO (2008). Climate change and

tourism: Responding to global challenges. Madrid:

United Nations World Tourism Organization 